\title{
Sustainable Evolution for Global Business: A Synthetic Review of the Literature
}

\author{
S. J. Chang ${ }^{1}$ \\ ${ }^{1}$ Illinois State University, USA \\ Correspondence: S. J. Chang, Illinois State University, USA. E-mail: sjchang@ilstu.edu
}

Received: October 3, 2015 Accepted: December 21, 2015 Online Published: February 25, 2016

doi:10.5539/jms.v6n1p1ＵRL: http://dx.doi.org/10.5539/jms.v6n1p1

\begin{abstract}
This paper reviews the recent literature on business sustainability. While it is almost impossible to give a universally agreeable definition of "sustainability" due to its scope, depth, and inclusive nature, this paper reviews a fairly large set of research efforts, both empirical and normative, that examine the sustainability issue in regards to the theoretical development, the interface between business and society, the interrelationships among firms, markets, and the public interest, sustainability measurement and assessment, as well as the changes, developments, and evolution in recent years along those lines. The uniqueness of the study is to review the literature by following the developmental and evolutionary sequences in business sustainability in order to shed light on how the concept of corporate sustainability has evolved from the traditional shareholders-focused neoclassical view and how it is advanced from the ideas of environmentalism, stakeholder theory, and CSR.
\end{abstract}

Keywords: business ethics, corporate social responsibility, stakeholder theory, sustainability, sustainable evolution

\section{Introduction}

Ever since it was first introduced by the Sierra Club in the 1970s, the term "sustainability" has been used in various areas with various meanings, and today it is probably one of the most overused buzzwords in business lexicon. When the term is mentioned, oftentimes other related buzzwords are also spoken, such as corporate social responsibility (CSR), environmentalism, stakeholder theory or stakeholderism, triple bottom line (TBL), green business, 3-P (people, planet, and profits) business, socially responsible investing (SRI), corporate citizenship, ecopreneur, natural capitalism, sustainable value added (SVA), and so forth. With growing concerns over the long-run welfare of diverse corporate stakeholders, these phrases are increasingly superseded by the broader term, "corporate sustainability."

Thanks to continuous expansion and proliferation of global business, today people, capital, information, and technology travel more freely, rapidly, and widely than ever, and thus impact the society more widely and deeply than ever. In this rapidly changing environment, global businesses act as evolutionary change agents for the creation of a sustainable global civilization (Laszlo, 2001; Van Marrewijk, 2003; Benn, Dunphy, \& Griffiths, 2006; Dunphy, Griffiths, \& Benn, 2007; Visser \& Crane, 2010; Hoffman, Badiane, \& Haigh, 2012). In 1987 "Our Common Future," the so called Brundtland Commission Report by the World Commission on Environment and Development (1987) formally described sustainable development as "development that meets the needs of the present without compromising the ability of future generations to meet their own needs".

Within more academic management circles, Elkington (1994) proposed the concept of the triple bottom line (TBL) based on the idea that business goals are inseparable from the society and environment, which is essentially consistent with the corporate sustainability concept. Hawken, Lovins, \& Lovins (1999) suggested the idea of natural capitalism where proper design and conceptualization of products and services can produce better results with minimal negative impact upon the environment. Dyllick \& Hockerts (2002) also offer three types of capital —economic, natural, and social—in line with TBL and corporate sustainability.

Considering all the discussions transpired over the years, we may define corporate sustainability as an inclusive concept that encompasses a variety of social impact issues such as environmental protection, social justice, business ethics, governance, product safety, employee welfare, diversity, and community well-being. In a world of increased demand for social welfare, on the rise is a strong normative proposition that sustainability should be 
an essential imperative and an integral part of business strategy for every firm (Elkington, 1994; McIntosh, Leipziger, Jones, \& Coleman, 1998; Figge, Hahn, Schaltegger, \& Wagner, 2002; Wilson, 2003; Porter \& Kramer, 2006; Dunphy et al., 2007; McLamb, 2009; Nidumolu, Prahalad, \& Rangaswami, 2009; Hakensen, 2010; Martin, 2013; Johnson, 2014; Moura-Leite, Padgett, \& Galan, 2014; Polman, 2014).

In the wake of tremendous increase in research effort, the ever-heightening corporate alertness, and the rise in interest and popularity throughout business schools about corporate sustainability in recent years, there are now many sustainability initiatives and advocates that serve as commonly referenced frameworks for a variety of social-impact issues. Examples include the Aspen Institute, B Corporations, Business for Social Responsibility, Dow Jones Sustainability Index, Global Reporting Initiative, International Society of Sustainability Professionals, ISO 26000, MSCI ESG Ratings (formerly KLD), Natural Step, Sustainability Accounting Standards Board, and the UN Global Compact.

While a billion people still go to bed hungry, the richest 85 people have the same wealth as the bottom 3.5 billion (Polman, 2014). In the past 50 years, humans have consumed more resources than in all previous history (Eco-Cycle, 2011). An estimated $80 \%$ of the world's forests have already been lost to deforestation, and almost 800 species on earth have become extinct (Environmental Issues, 2012). In the past century the spread of goods for private use and consumption has run parallel to deterioration in the quality of life as a whole (Manzini, 2002). So, what can and should we do? In particular, what can and should businesses do?

Businesses are called upon to help resolve these issues because of their increasing power and impact upon society at large. They are held accountable because of their multi-functionality and far-reaching influence. Today a large global business is not merely a profit maker, but at the same time, a producer, consumer, market maker, innovator, cultural leader, political constituent, rule/standard setter, balancer of interests, nurturing community, and a micro infocosm (Prahalad, 1994; Shrivastava, 1995; Chang, 2008). There is a continued need for dialogue between business and society to gain public acceptance of globalization and technological breakthroughs. Businesses thus increasingly assume the major role in making the society a better place.

\section{Literature Reviewed}

This paper reviews the recent literature on business sustainability. There have been a number of literature review studies on corporate sustainability (Margolis \& Walsh, 2003; Salzmann, Ionescu-Somers, \& Steger, 2005; Etzion, 2007; Bertels, Papania, \& Papania, 2010; Benoit \& Vickery-Niederman, 2010; Bateh, Horner, Broadbent, \& Fish, 2014; Montiel \& Delgado-Ceballos, 2014; Van der Byl \& Slawinski, 2015; and Alhaddi, 2015). Most of these studies review the articles published in a certain set of journals or cover the articles addressing particular sustainability issues related to environmentalism, stakeholder theory, or CSR.

But the present study is more inclusive in that it doesn't limit the discussion topics or the publication sources. It is almost impossible to give a universally agreeable definition of "sustainability" due to its scope, depth, and inclusive nature. As a concept discussed in many academic and professional disciplines, sustainability is intellectually diverse in nature and draws researchers from all disciplines-economics, law, sociology, political science, education, psychology, biology, ecology, environmental engineering, technology, accounting, management, finance, marketing, and so forth.

Therefore, the sustainability literature is vast but severely fragmented. Again, sustainability can be viewed as a broad and inclusive concept subsuming those preceding ideas and related concepts. The inclusivity of sustainability is depicted in Figure 1. It shows sustainability concepts by circles of different size, but the circles are not concentric. Although the CSR discussion includes much of the stakeholder theory, the former does not subsume the latter. Likewise, the stakeholder theory embraces environmentalism, but does not completely cover it. Yet, sustainability is considered inclusive of all. 


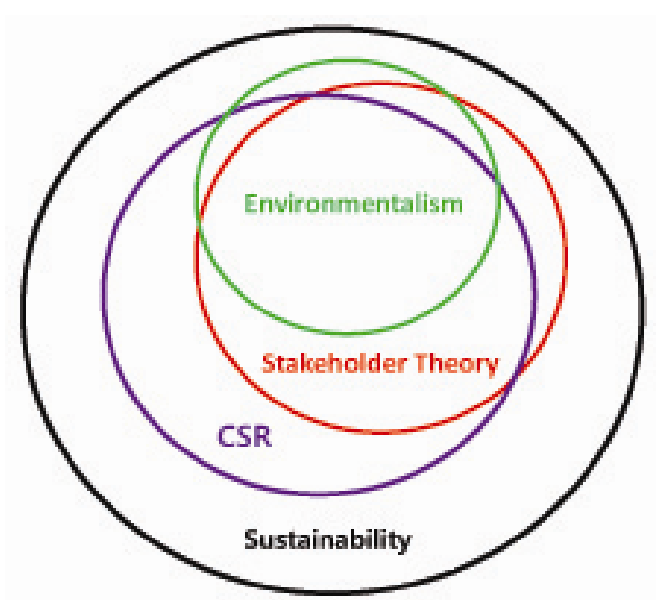

Figure 1. Inclusivity of sustainability

This paper reviews a large set of recent publications in the broad sustainability area that examined various normative and empirical issues in regards to the theoretical development, the interface between business and society, the interrelationships among firms, markets, and the public interest, sustainability measurement and assessment, as well as the changes, developments, and evolution along those lines. It covers published journal articles, books, surveys, industry reports, and other print and online publications from many different disciplines.

As Table 1 shows, of the total 215 items reviewed in this study, 153 (or $71.2 \%$ ) are articles published in various academic journals. The remainder is 24 books and 38 other publications. Of the 153 academic journal articles, 64 or $41.8 \%$ were identified from a set of journals in a broader discipline of management. 48 of them (31.4\%) were published in sustainability-related specialty journals covering the issues related to environmentalism, CSR, governance, stakeholderism, and business ethics. The remaining 41 articles (26.8\%) are from various disciplines including accounting, finance, marketing, economics, ecology, biology, and psychology. 186 or $86.5 \%$ of the 215 items reviewed were published in print or online since year 2000.

Table 1. Summary of the literature reviewed

\begin{tabular}{llll}
\hline Publication Source & \multicolumn{3}{l}{ Publication Year } \\
\cline { 2 - 3 } & $153(71.2 \%)$ & Before 1990 & $7(3.3 \%)$ \\
Books & $24(11.2 \%)$ & $1990 \mathrm{~s}$ & $22(10.2 \%)$ \\
Others* & $38(17.6 \%)$ & $2000 \mathrm{~s}$ & $102(47.4 \%)$ \\
Total Items Reviewed & 215 & $2010 \mathrm{~s}$ & $84(39.1 \%)$ \\
\hline & & Total Items Reviewed & 215 \\
\hline
\end{tabular}

Note. * Working papers, conference proceedings, practitioner articles, and survey/report items, printed and online

The uniqueness of the present study is that instead of some categorical review schemes such as theoretical vs. empirical reviews or issue-specific reviews, it reviews relevant articles by following the developmental and evolutionary sequences in business sustainability. The idea is to shed light on how the concept of corporate sustainability has evolved from the traditional shareholders-focused neoclassical view and how it is advanced from the ideas of environmentalism, stakeholder theory, and CSR. The study will hopefully bring insights to our understanding of corporate sustainability and help toward the advancement of sustainability agenda.

\section{Evolution}

\subsection{From SWM to CSR}

For thousands of years, business existed only at the fringes of society. Society thought little of people in business, and people in business expected little of society (Solomon \& Hanson, 1983). The infancy of modern business was triggered by the industrial revolution during the 18th century and supported by individualism and the Calvinist Protestant ethic. Although the origin of a corporate type of business dates back to the 11th century Italy, legally incorporated and shareholders-owned businesses rarely existed up until the turn of the twentieth century. Since then, they have exploded. 
The traditional corporate paradigm has long been centered on shareholders. The idea of shareholders' wealth maximization or SWM has been the dominant goal for corporate management, particularly in American business. Under this neo-classical view of SWM, the firm is managed solely in the interests of its shareholders (Brenner \& Cochrane, 1991; Key, 1999; Stormer, 2003). Naturally the old guards of this traditional view did not easily accommodate the ideas of CSR and stakeholder theory. Social and environmental concerns have typically been considered to conflict with financial goals.

Since Freeman (1984), Cornell \& Shapiro (1987), and Donaldson \& Preston (1995) popularized the idea of stakeholder theory or stakeholderism, it has gathered strength over the last several decades. However, the initial discussion about CSR and stakeholder theory dates further back. It has long been argued by organization theorists that the corporation should be considered as a coalition of interest groups with a stake (Berle \& Means 1932; Cyert \& March 1963). Advocates have been raising their voices contending strongly that corporate activity must be judged against the norm of societal welfare that constitutes, together with freedom, justice, and equality, the ultimate virtues that reign supreme in the minds of most human beings.

Managing the firm in the interests of its stakeholders, often referred to as the instrumental stakeholder theory, is basically a synthesis of the stakeholder concept, economic theory, behavioral science, and ethics (Jones, 1995). Suggesting the concept of 'nurture capital' in place of 'dominator capital' pursued by traditional businesses, Swenson (1996) earlier argued that businesses should be transformed from a pattern of domination to that of cooperation based on their relationships with affected entities. Numerous other researchers have contributed to understanding how the stakeholder theory can guide managerial decision and behavior in relation to CSR and sustainability (Wheeler \& Sillanpaa, 1997, Boatright, 1999; Bowie, 1999; Harrison \& Freeman, 1999; Hillman \& Keim, 2001; Buysse \& Verbeke, 2003; Roome, 2005; Doh \& Guay, 2006; Sen, Bhattacharya, \& Korschun, 2006; Barnett, 2007; Werther \& Chandler, 2011; Moura-Leite et al., 2014).

An argument against the stakeholder theory is that firms often cannot meet the expectations of all stakeholder groups simultaneously, and so they have to face trade-offs between the needs of different stakeholders (Key, 1999; Jensen, 2001). An early criticism against CSR practice was that it was only a PR exercise for enhancing corporate reputations. Hart \& Milstein (2003) observed that most managers frame sustainable development not as a multidimensional opportunity, but rather as a one-dimensional nuisance, involving regulations, added cost, and liability. Sen et al. (2006) noted that CSR awareness was still low and the impact of CSR was less pervasive than previously acknowledged.

At a more fundamental level Vogel (2005) states that CSR is best viewed as a complement rather than a substitute for more effective public policies. He argues that while it can be a useful tool alongside laws and regulations, CSR cannot completely replace them. Corporate Watch Report (2006) even challenges the concept of CSR by saying that CSR is of limited use in creating social change, a distraction from a more fundamental reform of the corporate structure, and thus a problem not a solution.

On the other hand, Husted \& Salazar (2006) establish an operational CSR framework and explain why organizations and society may be served better by strategic CSR than by coerced CSR. While a variety of corporate activities have been observed and analyzed in CSR literature (Ditlev-Simonsen \& Midttun, 2011), Bird, Hall, Momente, \& Reggiani (2007) document that CSR activities, independently or in aggregate, are valued in the market. The results of the literature study by Beurden \& Gössling (2008) also reveal that there is clear empirical evidence for a positive correlation between corporate social and financial performance.

When businesses are seen as fair and trustworthy by all stakeholder groups they are regarded as socially sustainable (Kaptein \& Wempe, 2001; Ambec \& Lanoie, 2008). While Ayuso, Rodriguez, Garcia, \& Arino (2007) find international empirical evidence that stakeholder engagement is positively related to financial performance, Kacperczyk's (2009) study on U.S. firms during 1991-2002 finds that firms that expand their attention to include non-shareholding stakeholders tend to experience higher shareholder value in the long run.

While firms with significant environmental concerns have to pay significantly higher credit spreads on their loans (Goss \& Roberts, 2011), firms with better environmental sustainability have significantly lower cost of equity (El Ghoul, Guedhami, Kwok, \& Mishra, 2011). Therefore, it is generally believed that better CSR practices can provide business advantages including better access to financial markets, lower capital costs, better employee and supplier relations, and better risk management.

As the perspectives on CSR's role shifted from defensive to strategic positions, many firms began to recognize CSR as a central component in business operations (Maxfield, 2008). While Visser (2010) proposes a continuum of CSR approaches, with stages ranging from defensive CSR through systemic CSR, Høivik \& Shankar (2011) suggest that there are advantages to moving from "doing CSR" to "being socially responsible." A general view is 
that by adopting sustainable practices, companies can gain competitive edge, increase their market share, and boost shareholder value. An empirical study by Moura-Leite et al. (2014) documents that nonparticipation in controversial business is already instrumental for a firm's market performance and tends to generate competitive advantage. This shows that stakeholderism could be a response to society's expectations.

Then the global financial crisis of 2007-2008, dubbed as a spectacular failure of neo-liberalism by Blackman (2008), has revealed severe shortcomings in corporate governance and an urgent need to reform the international financial regime. In the aftermath of the financial crisis, a large majority had lost trust in the free-market system, government and business. Furthermore, the growing economic inequality has been precipitating governmental policy interventions all around. Ghosh (2008), in particular, argues that some degree of socialization of financial systems as well as greater state involvement in economic activity is inevitable.

Such changes would undoubtedly place greater social roles and responsibilities on corporations, particularly large global businesses. In this new economic environment, businesses no longer have the right to operate unilaterally. Renewed concerns over the environmental degradation also came around to the front. Noting that from 1981 to 2005 the global GDP more than doubled, in contrast to the $60 \%$ of the world's ecosystems being degraded or used in an unsustainable manner, McLamb (2009) calls for global attention and investment in reforestation, renewable energy development, creating new green jobs in clean technologies and clean energy businesses, sustainable agriculture, and conservation-based enterprises.

In the meantime, the continued rapid expansion of e-commerce has produced a new concept of 'flow' factors in economy. Unlike the traditional 'stock' factors (i.e., capital, labor, and other real resources), information, technology, and other soft knowledge elements are now recognized as 'flow' factors that can provide dynamic and synergistic effects for the business and economy. Yet, business-driven pervasive technology tends to increase social disturbance and distortion by way of widening the so-called digital divide.

\subsection{Beyond CSR}

Such realization brings about an increasing recognition of the value of social contribution by sustainable businesses. Sustainable business may be defined as a business that entails minimal negative impact on the global and local environment, community, society, or economy (Werther \& Chandler, 2011). But a growing argument is that corporate responsibility should extend beyond avoiding value destruction. Businesses need to be more progressive, proactive, positive, and constructive in creating value for all. They should and can pursue sustainable development to create economically, socially, and environmentally balanced societies.

Notably Hahn (2011) provides a normative ethical reasoning for integration of CSR and sustainable development into holistic management thinking. Faupel \& Schwach (2010) state that corporate sustainable practices are those that satisfy the needs of the direct and indirect stakeholders, and Peloza, Loock, Cerruti, \& Muyot (2012) recognize the stakeholder reputation as the most valuable asset of a firm. Nadeem (2013) contends that holistic integration of corporate sustainability maximizes stakeholder value.

But the concept of sustainability remained unclear or even controversial. Dyllick \& Hockerts (2002) state that with the concept of sustainability so unclear, considerable more attention needs to be given to building a systematic theory of corporate sustainability. Marshall \& Brown (2003) note that the 1987 Brundtland definition did not provide any guide for action, while Banerjee (2003) argue that the usual definition of sustainable development is a capitalistic thought and its imposition on developing countries is problematic. Montiel (2008) surveys management literature and finds that researchers use both CSR and sustainability to refer to social and environmental issues, but there is no clear distinction between the two terms.

Salzmann et al. (2005) argue that there is an insufficient understanding of business logic for adopting corporate sustainability strategies. As a result, the ambiguity of the sustainability is still frequently mentioned in the literature (Aras \& Crowther, 2008; Hakensen, 2010; Linnenluecke \& Griffiths, 2010; Reinecke, Manning, \& von Hagen, 2012; Peloza et al., 2012; Valente, 2012; Alhaddi, 2015). Vallester, Lindgren, \& Moan (2012) note that many firms and practitioners remain in a state of confusion as to finding ways that would benefit both the firm and society at large. Interestingly, however, Montiel \& Delgado-Ceballos (2014) opine that the variability in the definition of corporate sustainability can be considered an advantage because the openness to accept different definitions has contributed to a richer discussion to the development of the field.

Nevertheless, by the time AICPA, CICA, and CIMA conducted a survey in 2010 covering 717 companies with more than 1,000 employees in the U.S., U.K., and Canada, it was revealed that nearly 80 percent of those firms had some sort of formal sustainability strategy in place (AICPA, 2010). The survey also reveals that the most critical drivers of business sustainability are profitability and strategic factors, followed by compliance, 
reputational risk, cost cutting and efficiency. According to the 2010 UN Global Compact-Accenture Study "A New Era of Sustainability," $93 \%$ of CEOs see sustainability as important to their company's future success. In another survey on business sustainability by McKinsey \& Company (2011), 57 percent of 2,956 corporate executives said that their companies had already integrated sustainability into strategic planning by 2011 .

Although there is still ambiguity and inconsistency in sustainability definition, a large portion of scholars now agree on a three-dimensional definition of sustainability that pursues economic prosperity, environmental quality, and social justice, which is consistent with the TBL concept (Elkington, 1994; Kaptein \& Wempe, 2001; Dyllick \& Hockerts, 2002; Hart \& Milstein, 2003; Bansal, 2005; Szekely \& Knirsch, 2005; Collins, Steg, \& Koning, 2007; Epstein, 2008; Bocken, Short, Rana, \& Evans, 2013; Aragón-Correa, 2013; Starik, 2013; Montiel \& Delgado-Ceballos, 2014; Johnson, 2014; Van der Byl \& Slawinski, 2015). Sustainable businesses are financially profitable, environmentally friendly, socially equitable and economically empowering businesses. While driving corporate performance, they positively contribute to the society by proactively addressing many critical issues simultaneously and collectively.

It is no secret that as much as society wants business to be pro-society, business wants society to be pro-business. Fukuyama (1999) views a healthy public-private partnership as a norm for social capital. Along this line, Chang (2008) argues that a new reciprocity framework is needed to allow business to properly monitor and assess society's attitude toward business in terms of corporate taxation and regulations, business infrastructure, community support, and related policy-making.

Business-society reciprocity may well be the key to sustainable and symbiotic progress for all as it empowers and enables businesses to pursue value creation and wealth distribution that will benefit all. Reciprocity ensures that both society and business are transparent to each other and they co-create social value which determines the commensurate social compensation for both. In this context, the roles of the government in regards to taxation, regulations, policy-making, infrastructure, and support loom large. Hence, the reciprocity may take a triangular form partnering government, business, and people (or society at large) as seen in Figure 2.

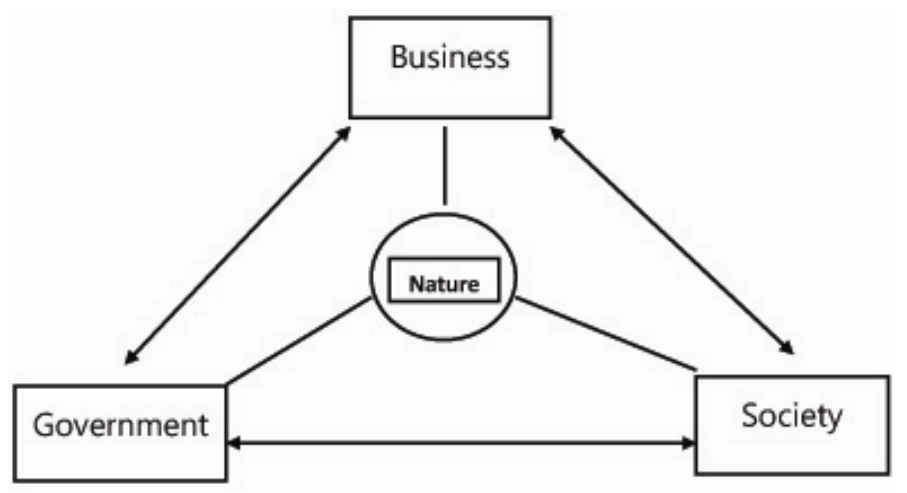

Figure 2. Triangular reciprocity structure

Based on the value-belief-norm theory as the basis of support for a social movement (Stern, Dietz, Abel, Guagnano, \& Kalof, 1999), Andersson, Shivarajan, \& Blau (2005) develop a theoretical framework for ecological sustainability support behavior. While Kock, Santaló, \& Diestre (2012) use the traditional stakeholder theory to explain firms' drivers for undertaking sustainability strategies, Schaltegger et al. (2012) propose a framework for business model innovation as a means to strategically create business cases on a regular basis as an inherent, deeply integrated element of business activities.

Peattie (2001) reviews the early development in marketing effort from 1) ecological marketing to 2) environmental marketing and to 3) sustainable marketing. While McDonald \& Oates (2006) examine how consumers view firms' sustainable marketing activities, Vorhies \& Morgan (2005) maintain that a firm's marketing capabilities positively influence its sustainability performance. However, as in other business functional areas, there is little consensus as to the place for sustainability in marketing. Jones, Clarke-Hill, Comfort, \& Hillier (2007) report that some believe that marketing and sustainability cannot be reconciled, while others argue that marketing can contribute to the development of sustainable consumption.

Jeucken (2005) contends that although banking and finance play a fundamental role in "social success," financial sector in general is largely ignorant and negligent about the rationale and pressures for sustainability. Sustainable 
finance extends the behavioral and pure financial goals of the company to a broader horizon than shareholders' interest alone. Arguing that in a sustainable economy, corporate residuals belong to stakeholders, not just shareholders, Soppe (2009) suggests that finance urgently needs a 'sustainability approach' to connect the CSR initiatives with socially responsible investing in the capital market.

Many studies have documented that alongside environmental risk management, good sustainability practices in employee relations, product safety, and governance positively influence the cost of capital (Verwijmeren \& Derwall, 2010; El Ghoul et al., 2011; Lima \& Sanvicente, 2013). In the meantime, Sontag-Padilla, Staplefoote, and Morganti (2012) advocate that nonprofit organizations should establish financial sustainability as a dynamic and continual process and create a clear strategic plan that defines the social mission and builds programs, community support, and collaborative partnerships.

Researchers stress the importance of top management support in developing sustainability culture (Berry, 2004; Dixon \& Clifford, 2007; Ángel del Brío, Junquera, \& Ordiz, 2008). Corporate sustainability practices are also influenced by institutional ownership, stakeholder activism, customer pressures, NGOs, and political institutions (Husted \& Allen, 2006; Kassinis \& Vafeas, 2006; Neubaum \& Zahra, 2006; Doh \& Guay, 2006; Rueda-Manzanares, Aragón-Correa, \& Sharma, 2008; Delmas \& Montiel, 2009; Ditlev-Simonsen \& Midttun, 2011; Surroca, Tribó, \& Zahra, 2013).

Upon hypothesizing that shareholder activism and regulatory threats are likely to lead firms to adopt socially acceptable practices, Reid \& Toffel (2009) find empirical evidence of direct and spillover effects. Bateh et al. (2014) state that organizational leaders may often develop a narrow view of sustainability and consider only the aspects of sustainability that are directly related to their sphere of performance. This, labeled "internal sustainability" by Raatzsch (2012), is concerned with survival in a competitive market, which increasingly includes global competition. Internal sustainability also relates to maintenance of core principles or purposes as external pressures may necessitate changes in operations and policies.

Yet, sustainability issues impact all business and non-business organizations also in terms of labor exploitation, environmental pollution, resource depletion, and overall quality of life issues. More and more organizations now move to the forefront of this "external sustainability." Businesses and organizations that pursue both internal and external sustainability exist not only for an economic purpose but also for a social purpose. They may be labeled social enterprise or social entrepreneur.

Anita Roddick at the Body Shop and Ben Cohen of Ben \& Jerry's are recognized as early social entrepreneurs with a strong environmental commitment (Wycherley, 1999; Blowfield, 2013). But the increasing attention toward social enterprise has produced many examples of sustainable business strategies and practices of such well-known companies as Barclays, BMW, Coca-Cola, Daimler, DuPont, GE, Ford, HP, Intel, Nestlé, Nike, Novo Nordisk, PepsiCo, Shell, Starbucks, Tata, Unilever, and Wal-Mart (Wei-Skillern, 2004; Nadkarni et al., 2008; Sotorrio \& Sanchez, 2008; Magee, 2009; Haugh \& Talwar, 2010; Porter, Hills, Pfitzer, Patscheke, \& Hawkins, 2012; Straková, 2012; Savitz, 2013; Sharma, 2013b; and Polman, 2014). Recently attention has also been drawn to new and smaller firms such as Acumen Fund, Benetech, Just Business, The Hub, and Toms Shoes for their social enterprise practices.

The concept of social enterprise is similar to that of "benefit corporations," that are incorporated in some twenty states in the U.S. as legally obligated to pursue a social benefit in addition to their responsibility to the shareholders (Hiller, 2013). Separately, "B Corps" are firms certified by B Lab, a non-profit organization, as having met a certain set of standards for social and environmental performance (B Lab, 2013). Interestingly, Shrivastava \& Kennelly (2013) contend that "place-based enterprises," whose resources, productive activities, and ownership are anchored in specific local places, may be more likely than conventional enterprises to pursue locally beneficial economic, social, and environmental outcomes.

\subsection{Towards Sustainable Value Creation}

While the dominant business model has arguably been threatening human survival (Metcalf \& Benn, 2013), the early sustainability effort was basically an "add-on" to what remain essentially unsustainable business operations (Markevich, 2009). So, firms may have devolved considerably in recent decades, but they must and will continue to evolve. Polman (2014) argues that while social responsibility and philanthropy are very important, businesses in the future will have to go beyond that and make a positive contribution to the society.

As the focus shifts from value protection or preservation to value creation or generation for the society, businesses are given a mandate under the corporate sustainability norm. Today every business has to be a social entrepreneurship voluntarily and actively engaging in the fight for poverty, healthcare delivery, climate change 
and environmental protection, habitat destruction and biodiversity loss, public school funding, technological capability, and human rights improvement. Every business should be willing to act as a source of peace, love, and service. Every business should use innovation to better the environment and social living.

Intuitively societal development can be sustainable only when new value is created without destroying the existing value. In terms of various kinds of capital a society pursues such as natural capital (natural resources), man-made capital (produced goods), human capital (knowledge and skills), and social capital (customer/community relations), the question is can we increase one particular kind of capital without destroying other capitals. This concept is known as "strong sustainability" (Pearce, Markandya, \& Barbier, 1989; Stern, 1997; Daly, 1999; Neumayer, 1999; Atkinson, 2000; Figge \& Hahn, 2004). As opposed to a neoclassical view of "weak sustainability," which regards all capitals as substitutable with each other, strong sustainability requires that each form of capital is kept constant.

Figge \& Hahn (2004) then propose a new approach to measure corporate contributions to sustainability called "sustainable value added (SVA)." Based on the concepts of opportunity costs and strong sustainability, SVA considers simultaneously economic, environmental, and social aspects, and measures whether a company creates extra value while ensuring that every environmental and social impact is in constant. Since then, many studies have utilized SVA and developed similar measures such as market sustainable value added and total sustainable value added (Hahn, Figge, \& Barkemeyer, 2007; Kuosmanen \& Kuosmanen, 2009; Van Passel, Van Huylenbroeck, Lauwers, \& Mathius, 2009; Faupel \& Schwach, 2010; Straková, 2012).

Nidumolu et al. (2009) propose a five-stage path for businesses to follow and become more sustainable: (1) Viewing compliance as opportunity, (2) Making value chains sustainable, (3) Designing sustainable products and services, (4) Developing new business models, and (5) Creating next-practice platforms. Sustainable management seeks good alignment between environmental and economic objectives of the company as resource efficiency translates directly into cost savings. Recognizing unique complications and challenges in capturing shared value, Porter et al. (2012) suggest more pragmatic approaches for measuring shared value.

Gupta \& Benson (2011) compare the risk-adjusted performance of U.S. companies in the annual Innovest "Global 100" rankings with that of the more than 8,000 U.S. firms and conclude that firms with superior environmental, social, and governance policies do not significantly underperform the market. In the meantime, new hybrid business models are also offered that employ market tactics to address social and environmental issues (Boyd, Henning, Reyna, Wang, \& Welch, 2009; Hoffman et al., 2012; Pache \& Santos, 2013).

Building on some sustainable business models offered by Stubbs and Cocklin (2008), Bocken, Short, Rana, \& Evans (2014) further develop sustainable business model archetypes mainly for manufacturing business. But some of them are general enough to apply to business in general: "Re-purpose the business for environment and society; Integrate business in the community; Encourage sufficiency; Adopt a stewardship role instead of ownership; and Develop and deliver scale-up sustainable solutions."

Bruyninckx (2014) argues that businesses should help 'green' the whole economy by changing the way they produce goods and services. Lülfs \& Hahn (2014) apply an action determination model for ecological behavior to the business sphere and provide a framework for fostering corporate sustainable behavior. All in all, there is a consensus that social, environmental and economic demands are considered the three pillars of corporate sustainability (Elkington, 1994; Kaptein \& Wempe, 2001; Dyllick \& Hockerts, 2002; Hart \& Milstein, 2003; Bansal, 2005; Szekely \& Knirsch, 2005; Collins et al., 2007; Epstein, 2008; Bocken et al., 2013; Aragón-Correa, 2013; Starik, 2013; Montiel \& Delgado-Ceballos, 2014; Johnson, 2014; Van der Byl \& Slawinski, 2015).

In light of the foregoing, we may identify four stages of evolution in social Ideals and the corresponding corporate objectives as shown in Table 2. The recent evolution points toward a shift in social ideals from the self-interest-based pursuit of prosperity to the affirmation of societal interests based on sustainability. Accordingly, corporate objectives have evolved from the traditional SWM to the SWM subject to other stakeholders' interests (particularly those of direct, local stakeholders such as employees), to the CSR-driven value maximization, and to the maximization of sustainable value added.

At its most advanced stage, therefore, business sustainability means creating and maximizing social, environmental, and economic values concurrently and collectively. This is the idea of 'shared value creation'-creating value to be shared by all including customers, investors and shareholders, employees, suppliers and partners, the environment, and society (Porter \& Kramer, 2011). The good news is that according to numerous empirical studies, business profitability and sustainability are not incompatible but complementary (Hillman \& Keim, 2001; Smithley-Fulmer, Gerhart, \& Scott, 2003; Core, Guay, \& Rusticus, 2006; Cremers \& Ferrell, 2009; Godfrey, Merrill, \& Hansen, 2009; Statman \& Glushkov, 2009; Giroud \& Mueller, 2011; Jo \& 
Harjoto, 2011; Nadeem, 2013; Servaes \& Tamayo, 2013; Clark, Feiner, \& Viehs, 2014).

Table 2. Evolution in social ideals and corresponding corporate objectives

\begin{tabular}{ll}
\hline Social Ideals & Corporate Objectives \\
\hline Self-Interest-Based & Shareholders' Wealth \\
Happiness or Utilitarianism & Maximization (SWM) \\
\hline Rights-Based Fairness or & Stakeholderism- \\
Justice & Constrained SWM \\
\hline Morality/Duty-Based CSR or & CSR-Driven Value \\
Commensalism & Maximization \\
\hline Sustainability-Based Progress or & Maximization of Sustainable \\
Sustainable Social Evolution & Value Added \\
\hline
\end{tabular}

\subsection{From What and Why to How}

As noted above, it has been argued that the current prevailing business models are increasingly outmoded with negative externalities and thus preventing firms from becoming sustainable. Given the globalism, technology, and social alertness, we probably cannot go back to the U.S. 1950s-style social contract. Again, fundamental changes to traditional business models are needed to respond to societal, natural, and business needs of sustainable development (Stubbs \& Cocklin, 2008; Kelly \& White, 2009; Birkin, Cashman, Koh, \& Liu, 2009; Schaltegger et al., 2012; Bocken et al., 2014).

But how can firms act to contribute to shared prosperity and long-term sustainable growth? How can they embed or incorporate sustainability into company strategies, operations, and culture? Which practices are most effective? Obviously just installing a Chief Giving Officer or a Chief Sustainability Officer cannot achieve the goal. Zollo, Cennamo, \& Neumann (2013) develop a conceptual framework to explore the process from its historical focus on definitional ("what") and motivational ("why") questions to the understanding of change and learning process questions ("how").

Early on Hart \& Milstein (2003) developed a sustainable value framework to help identify strategies and practices that contribute to a more sustainable world while simultaneously driving shareholder value. Muthuri, Matten, \& Moon (2007) explore how corporations contribute to social capital creation through the dynamics of improving community relations. Stead \& Stead (2008) suggest that firms can obtain a competitive advantage through both process-driven and market-driven sustainability strategies.

Noting the importance of within-firm sustainability communication, Colbert \& Kurucz (2007) and Doppelt (2008) suggest that all HR development be infused with sustainability themes and employees be continuously updated with new information about sustainability. Siebenhüner \& Arnold (2007) note that setting ambitious sustainability objectives can stimulate new ways of thinking and recommend allowing flexibility and autonomy for implementing those objectives. However, Graham \& Bertels (2008) caution that increasing sustainability awareness provides only a limited blueprint for how sustainability should be implemented on a micro level.

While Pfeffer (2010) suggests that firms need to focus on human as well as physical resources, Haugh \& Talwar (2010) show how large firms utilize technical and social learning to embed sustainability across the organization. Linnenluecke \& Griffiths (2010) explore the link between organization culture and the pursuit of corporate sustainability by assessing (1) what constitutes a sustainability-oriented organizational culture, (2) whether it is possible for organizations to display a unified sustainability-oriented organizational culture, and (3) whether organizations can become more sustainable through culture change.

Esquer-Peralta, Velazquez, \& Munguia (2008) recommend putting existing systems related to environmental, CSR, and stakeholder management together under one sustainability management system. Maon, Lindgreen, \& Swaen (2009) propose a comprehensive sustainability training program covering everything from sustainability policies, programs, goals, and performance to all aspects of business operations, including suppliers, waste management, product design and life cycle, business partners, and government.

It is also suggested (mainly by practitioners) that firms utilize employee grassroots efforts by providing time, incentives, and rewards for conceiving and launching sustainability initiatives (Wirtenberg, Russell, \& Lipsky, 2008; Willard, 2009; Strandberg, 2009; Bertels et al., 2010). McWilliams \& Siegel (2011) apply a resource-based theory to show how value is created and captured through corporate social practices. Connelly, Ketchen, \& Slater (2011) apply organizational theories such as agency theory, social network theory, signaling theory, and 
transaction cost theory, to better understand the ways that firms engage in sustainable marketing practices.

Yet, Starik \& Kanashiro (2013) contend that none of the extant theories offer benefits and opportunities in assisting organizations to move toward sustainability. Wirtenberg et al. (2008) points to the need for strong commitment by corporate leadership which will allow the employees to fully embrace the sustainability culture. Eccles, Perkins, \& Serafeim (2012) state that to develop a broad-based commitment to sustainability, companies need leadership commitment, an ability to engage with multiple stakeholders along the value chain, widespread employee engagement and disciplined mechanisms for execution.

Sharma (2013a) defines sustainable value as the long-term and higher wealth for shareholders and well-being for stakeholders, which a company "co-creates" by engaging with different stakeholders on a range of issues constituting the company's value chain. Bocken et al. (2013) present a value mapping tool to help firms create balanced social, environmental, and economic value through integrating sustainability more fully into the core of their business. After reviewing different approaches to managing the tensions in corporate sustainability, Van der Byl \& Slawinski (2015) calls for balancing economic, social, and environmental goals, and applying conceptual work through empirical studies.

As sustainability touches a myriad of social impact issues, it is never an easy task for businesses to create sustainable value. However, they can and should move toward sustainability by developing new products and services as well as business processes and systems, deliberately engaging in practices that create and deliver sustainability values, and applying appropriate assessment tools for sustainability progress. In evolutionary biology, sustainable evolution means a "life-centric" perspective on very long term sustainability. It is a goal for every species, now including business. Business, like any other species, should develop and maintain the ability to continually adapt to changes and thereby survive. This evolution takes well-intended and carefully-coordinated effort from business, government, and society.

\section{Sustainability Assessment and Education}

While various initiatives, standards, tools, and instruments are continuously introduced in the CSR and sustainability literature (Strike, Gao, \& Bansal, 2006; Chen \& Delmas, 2011; Maas \& Liket, 2011; Walls, Berrone, \& Phan, 2012), it is still hard to measure a firm's contribution to sustainability unambiguously. Ever since Kaplan and Norton (1992) presented the balanced scorecard for both financial and operational reporting, many organizations have integrated some kind of sustainability indicator into their strategic planning, performance measurement, and decision-making (Figge et al., 2002; Lamberton, 2005; Nordheim \& Barrasso, 2007; Adams \& Frost, 2008; Bouten, Everaert, Van Liedekerke, De Moor, \& Christiaens, 2011).

Epstein (2008) offers discussion of quantifying and measuring the sustainability risks, benefits, and impacts. Corey (2009) reviews the role of sustainable development indicators in corporate decision-making and points out that there is a substantial room for further work on the use of sustainable development indicators. Reviewing many studies utilizing the data provided by the Kinder, Lydenberg, and Domini Indices (MSCI ESG Indices), the Global Reporting Initiative, and the Dow Jones Sustainability Index, Montiel \& Delgado-Ceballos (2014) argue that it is still unclear how the economic and social dimensions can be best measured.

As a practical framework of sustainability, the TBL may be used as an assessment measure for the performance of the business and the success of the organization in terms of economic, social, and environmental goals (Norman \& MacDonald, 2004; Dhiman, 2008; Goel, 2010; Rogers \& Hudson, 2011). Ho \& Taylor (2007), Morhardt (2009), and Jackson, Boswell, \& Davis (2011), among others, discuss the advantages and drawbacks of TBL reporting, and find that there is a very wide range of reporting quality.

Some researchers address "ESG" - environment, society, and governance — as a similar configuration of three dimensions of sustainability and find a positive correlation between ESG performance and overall performance (Godfrey et al., 2009; Hespenheide \& Koehler, 2012; Porter et al., 2012; Clark et al., 2014). But the governance can be included in the economic dimension of the more inclusive TBL concept.

Benoit \& Vickery-Niederman (2010) present a sustainability reporting system designed to provide monitoring measures, indicators, and evaluations. Jensen \& Berg (2012) apply institutional theory in their sustainability reporting analysis. The recent trend is to promote integrated reporting, which is a holistic and integrated representation of the company's performance in terms of both finance and sustainability. Although third party verification is a norm for financial reporting (e.g., CPA audits), it is still less prevalent for sustainability reporting. Yet it is on the rise and increasingly viewed as important for credibility (Blackburn, 2007).

Gregory \& Whittaker (2013) points out the inability of the conventional test method to correctly ascertain the positive CSR value. They argue that markets indeed place a positive value on CSR but that is not detected by 
conventional returns-based tests. Based on an extensive literature review Montiel \& Delgado-Ceballos (2014) show that the field is still evolving and different approaches to define, theorize, and measure corporate sustainability are used, and as such, a standardized method to measure corporate sustainability does not exist.

Noting that the effects of corporate social responsibility on financial performance vary across firms and time, Barnett (2007) develops a stakeholder influence capacity to explain this variability. Whereas Russo and Fouts (1997) find evidence that 'it pays to be green,' Aguilera-Caracuel \& Ortiz-de-Mandojana (2013) later observe that green innovative firms do not experience improved financial performance. Mattingly (2015) reports that corporate social performance tends to produce positive outcome in accounting measures but not necessarily in stock returns, which is in line with the earlier findings of Orlitzky, Schmidt, \& Rynes (2003).

Ricart, Rodriguez, \& Sanchez (2006) examine how corporate governance systems are evolving to accommodate the consideration of sustainable development issues and suggest that the corporate leaders pay close attention to sustainability agenda. Walls et al. (2012) point out that empirical research on the impact of corporate governance on corporate social performance has also produced fragmented and contradictory results. Bertels et al. (2010) note that it is difficult to identify the dependent and independent variables in many studies and there is a need for much more clarity in relevant constructs for sustainability studies.

As everyone seems to be talking sustainability, colleges and universities, particularly business schools, now recognize it as important knowledge for students to learn (Moon \& Orlitzky, 2011; DiMeglio, 2012). However, while the popularity of sustainability education is on the rise, Peters \& Caro (2014) suggest that many academics professionally and personally, still feel like Sisyphus when trying to incorporate sustainability into mainstream business education. They note that it seems as if it always requires more validation and evidence to be recognized and represented as an integral part of higher education.

\section{Synthesis}

Whether motivated by concern for society and the environment, government regulation, stakeholder pressures, or economic profit, businesses are evolving to be sustainability-oriented. This is because while short-term economic gain could be chased, a failure to account for social and environmental impacts would make business practices unsustainable. So, the next frontier for businesses is not just 'doing less bad' but 'doing more good.'

The most relevant sustainability trends are related to organizational leadership, change, and culture, as well as sustainability accounting and reporting (Bateh et al., 2014). Johnson (2014) suggests that firms must map their path of sustainability in a way that is meaningful for them, while meeting the needs of their stakeholders. Coombs \& Holladay (2015) point out the importance of CSR communication since most stakeholders are uninformed about corporate CSR efforts.

As businesses take the lead as a change agent for corporate sustainability, strong leadership and 'buy-in' are needed. Indeed, as corporate sustainability keeps evolving, we are witnessing a paradigmatic shift in business thinking and planning, which ultimately changes the way businesses are conducted. This is a change in basic assumptions within the ruling theory of science. Key operational goals should span across the 1) economic, 2) environmental, and 3) social aspects of the business. Examples include, but are not limited to: 1) Economic: customer relationship management, governance, risk and crisis management, financial reporting and even taxation; 2) Environment: resource use, emissions, water and energy management and environmental reporting; and 3) Social: talent attraction and retention, safety performance, labor relations and social reporting.

While driving corporate performance, sustainable businesses positively contribute to the economy and society by proactively addressing many critical issues as shown in Figure 3. These issues are compiled and synthesized from the various studies referenced throughout this paper and categorized under the three pillars of corporate sustainability agenda based on the business-society-government reciprocity. 


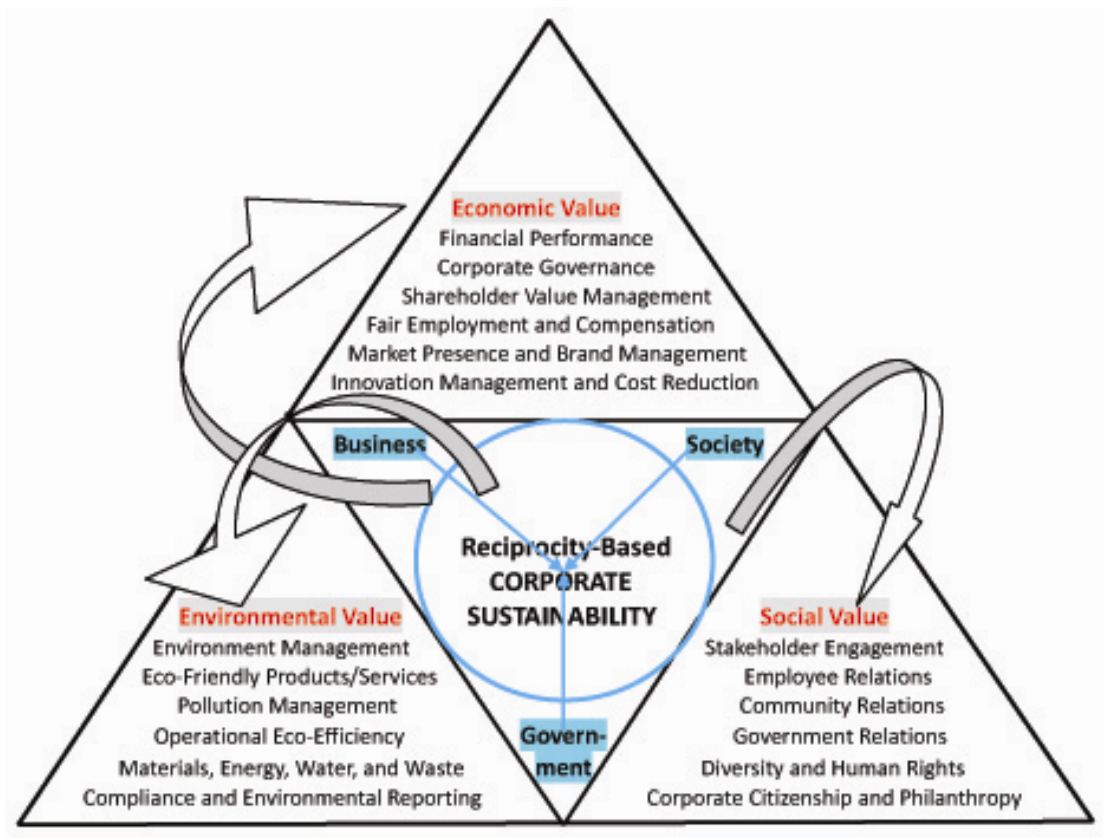

Figure 3 . Sustainability value chain —a synthesis

The sustainability value chain diagram in Figure 3 may take a different shape or form depending on how corporate sustainability is understood in terms of its underlying philosophies, dimensions, and extents. For example, the diagram may be drawn as a set of concentric circles with business in the inmost circle and economy, society, and environment in the outer circles. But such depiction may imply that the firm itself (i.e., its well-being or profitability) is more important than the others in the outer circles, whereas Figure 2 portrays an evenly balanced triangle for economic, social, and environmental values that firms would pursue simultaneously and collectively.

As business strives to harmonize these values, it can evolve into a system that can lead to the greatest efficiency in allocating resources and to the greatest economic good for the greatest number in the society. Businesses should envision sustainability as part of the implementation continuum, be intentional about building a corporate culture that supports the sustainability agenda, and make continuous attempts to evolve for sustainability.

\section{Future Research Directions}

Many issues remain unresolved. There is insufficient evidence of the problem, or insufficient knowledge about whether or how a policy or action could contribute to more sustainable forms of development. Little work has been done in terms of incorporating sustainability into organizational culture. There is a lack of evaluation and assessment. Existing research has been fragmented or focused only on certain issues in isolation. There is also a serious normative issue related to power and politics regarding sustainability.

The following list is presented to provide some potentially meaningful and feasible research directions (not in any order) for further study in corporate sustainability.

- Identifying the most relevant sustainability parameters for operational performance and investment returns and defining constructs for the independent and dependant variables for empirical studies.

- Measuring the size of a firm's contribution to increased sustainability (sustainability value added) in terms of its three - economic, environmental, and social — dimensions.

- Examining whether the three dimensions of corporate sustainability are equally valid and important.

- Analyzing the non-financial performance and impact of sustainability practices on firm-level performance measures.

- Investigating consistencies and inconsistencies in empirical results of corporate sustainability practices.

- Building evidence base for promising practices in sustainability and investigating the availability and utilization of various sustainability indicators for corporate strategy and decision-making. 
- Investigating the influence of industry, geography, and culture on the adoption of sustainability approach to corporate governance.

- Conducting comparative analysis on long-term performance of companies perceived to be pro-sustainability versus companies perceived to engage in controversial businesses and practices.

- $\quad$ Conducting empirical investigations and comparative studies for firms at different stages of sustainability implementation and determining the effectiveness of sustainability practices.

- $\quad$ Exploring questions about how companies present themselves publicly (for example on social media) in designing and executing their overall sustainability campaign, how the public perceives it, and consequently how the public perception affects firms' performances.

- Developing sustainability balance sheets and statements and investigating the changing requirements for sustainability reporting and disclosure and how companies prioritize sustainability topics and non-financial metrics to disclose.

- Developing curricular projects linked to sustainability needs and benefits and exploring ways to include systematic approaches to sustainability in business education.

- Examining whether the current sustainability phenomenon is driven by corporate practitioners or by academicians and who sets the standards.

\section{References}

Adams, C. A., \& Frost, G. R. (2008). Integrating sustainability reporting into management practices. Accounting Forum, 32(4), 288-302. http://dx.doi.org/10.1016/j.accfor.2008.05.002

Aguilera-Caracuel, J., \& Ortiz-de-Mandojana, N. (2013). Green innovation and financial performance: An institutional approach. Organization \& $\quad$ Environment, $365-385$. http://dx.doi.org/10.1177/1086026613507931

AICPA, CICA, \& CIMA. (2010). Evolution of corporate sustainability practices: Perspectives from the UK, US and Canada. AICPA, CICA and CIMA Research Study. Retrieved from http://www.cimaglobal.com/Documents/Thought_leadership_docs/CIMA_AICPA_CICA\%20sustainability _report.pdf

Alhaddi, H. (2015). Triple bottom line and sustainability: A literature review. Business and Management Studies, 1(2). http://dx.doi.org/10.11114/bms.v1i2.752

Ambec, S., \& Lanoie, P. (2008). Does it pay to be green? A systematic overview. Academy of Management Perspectives, 22(4), 45-62. http://dx.doi.org/10.5465/AMP.2008.35590353

Andersson, L., Shivarajan, S., \& Blau, G. (2005). Enacting ecological sustainability in the MNC: A test of an adapted value-belief-norm framework. Journal of Business Ethics, 59, 295-305. http://dx.doi.org/10.1007/s10551-005-3440-x

Ángel del Brío, J., Junquera, B., \& Ordiz, M. (2008). Human resources in advanced environmental approaches-A case analysis. International Journal of Production Research, 46(21), 6029-6053. http://dx.doi.org/10.1080/00207540701352094

Aragón-Correa, J. A. (2013). Beyond ourselves: Building bridges to generate real progress on sustainability management issues. Organization \& Environment, 26(1), 3-6. http://dx.doi.org/10.1177/1086026613476520

Aras, G., \& Crowther, D. (2008). Governance \& sustainability: An investigation into the relationship between corporate governance and corporate sustainability. Management Decision, 46(3), 433-448. http://dx.doi.org/10.1108/00251740810863870

Atkinson, G. (2000). Measuring corporate sustainability. Journal of Environmental Planning and Management, 43, 235-252. http://dx.doi.org/10.1080/09640560010694

Ayuso, S., Rodriguez, M. A., Garcia, R., \& Arino, M. A. (2007). Maximizing stakeholders' interests: An empirical analysis of the stakeholder approach to corporate governance. University of Navarra Working Paper No. 670. http://dx.doi.org/10.2139/ssrn.982325

Banerjee, S. B. (2003). Who sustains whose development? Sustainable development and the reinvention of nature. Organization Studies, 24, 143-180. http://dx.doi.org/10.1177/0170840603024001341

Bansal, P. (2005). Evolving sustainably: A longitudinal study of corporate sustainable development. Strategic Management Journal, 26, 197-218. http://dx.doi.org/10.1002/smj.441 
Barnett, M. (2007). Stakeholder influence capacity and the variability of financial returns to corporate social responsibility. Academy of Management Review, 32, 794-816. http://dx.doi.org/10.5465/AMR.2007.25275520

Bateh, J., Horner Jr., D. H., Broadbent, A., \& Fish, D. (2014). Towards a theoretical integration of sustainability: A literature review and suggested way forward. Journal of Sustainability Management, 2(1), 35-42.

Benn, S., Dunphy, D., \& Griffiths, A. (2006). Enabling change for corporate sustainability: An integrated perspective. Australasian Journal of Environmental Management, 13(3), 156-165. http://dx.doi.org/10.1080/14486563.2006.10648683

Benoit, C., \& Vickery-Niederman, G. (2010). Social sustainability assessment literature review. The Sustainability Consortium. White Paper \#102. Arizona State University and University of Arkansas.

Berle Jr., A., \& Means, G. C. (1932). The modern corporation and private property. New York: Macmillan.

Berry, G. R. (2004). Environmental management: The selling of corporate culture. Journal of Corporate Citizenship, 16, 71-84. http://dx.doi.org/10.9774/GLEAF.4700.2004.wi.00010

Bertels, S., Papania, L., \& Papania, D. (2010). Embedding sustainability in organizational culture: A systematic review of the body of knowledge. Network for Business Sustainability. Retrieved from http://nbs.net/wp-content/uploads/Systematic-Review-Sustainability-and-Corporate-Culture.pdf

Beurden, P., \& Gössling, T. ( 2008). The worth of values-A literature review on the relation between corporate social and financial performance. Journal of Business Ethics, 82(2), 407-424. http://dx.doi.org/10.1007/s10551-008-9894-x

Bird, R., Hall, A. D., Momente, F., \& Reggiani, F. (2007). What corporate social responsibility activities are valued by the market? Journal of Business Ethics, 76, 189-206. http://dx.doi.org/10.1007/s10551-006-9268-1

Birkin, F., Cashman, A., Koh, S., \& Liu, Z. (2009). New sustainable business models in China. Business Strategy and the Environment, 18(1), 64-77. http://dx.doi.org/10.1002/bse.568

B Lab. (2013). B Corporation. Retrieved from http://www.bcorporation.net/

Blackburn, W. (2007). The sustainability handbook: The complete management guide to achieving socialeconomic and environmental responsibility. Washington, DC: Environmental Law Institute.

Blackman, C. N. (2008). The global financial crisis and the collapse of the neo-liberal paradigm. The Economy 2008: Planning in a Turbulent Environment. University of West Indies, October 8th, 2008 Conference. Retrieved from http://www.ccmf-uwi.org/files/publications/misc/courtney_blackman/THEGLOBALFINANCIALCRISISA NDTHECOLLAPSEOF.pdf

Blowfield, M. (2013). Business and sustainability. Oxford: Oxford University Press.

Boatright, J. R. (1999). Ethics in Finance. Boston, MA: Blackwell. http://dx.doi.org/10.1002/9780470998397.ch13

Bocken, N. M. P., Short, S. W., Rana, P., \& Evans, S. (2013). A value mapping tool for sustainable business modeling. Corporate Governance, 13(5), 482-497. http://dx.doi.org/10.1108/CG-06-2013-0078

Bocken, N. M. P., Short, S. W., Rana, P., \& Evans, S. (2014). A literature and practice review to develop sustainable business model archetypes. Journal of Cleaner Production, 65, 42-56. http://dx.doi.org/10.1016/j.jclepro.2013.11.039

Bouten, L., Everaert, P., Van Liedekerke, L., De Moor, L., \& Christiaens, J. (2011). Corporate social responsibility reporting: A comprehensive picture? Accounting Forum, 35(3), 187-204. http://dx.doi.org/10.1016/j.accfor.2011.06.007

Bowie, N. (1999). Kantian capitalism. Boston, MA: Blackwell.

Boyd, B., Henning, N., Reyna, E., Wang, D. E., \& Welch, M. D. (2009). Hybrid organizations: new business models for environmental leadership. Sheffield, UK: Greenleaf Publishing Limited.

Brenner, S., \& Cochrane, P. (1991). The stakeholder theory of the firm: implications for business and society theory and research. International Association for Business and Society Proceedings, 449-467.

Bruyninckx, H. (2014, April 30). Greening the entire economy: Not just a handful of new sectors. Ecology 


\section{Communications Group-Business \& Economy. Retrieved from} http://www.ecology.com/2014/04/30/greening-entire-economy-just-handful-new-sectors/

Buysse, K., \& Verbeke, A. (2003). Proactive environmental strategies: A stakeholder management perspective. Strategic Management Journal, 24(5), 453-470. http://dx.doi.org/10.1002/smj.299

Chang, S. J. (2008). Business-society reciprocity as a guideline for global corporate governance. International Finance Review, 9, 81-96. http://dx.doi.org/10.1016/S1569-3767(08)09004-3

Chen, C.-M., \& Delmas, M. (2011). Measuring corporate social responsibility: An efficiency perspective. Production and Operations Management, 20, 789-804. http://dx.doi.org/10.1111/j.1937-5956.2010.01202.x

Cheung, A. W. K. (2011). Do stock investors value corporate sustainability? Evidence from an event study. Journal of Business Ethics, 99, 145-165. http://dx.doi.org/10.1007/s10551-010-0646-3

Clark, G. L., Feiner, A., \& Viehs, M. (2014). From the stockholder to the stakeholder: How sustainability can drive financial outperformance. University of Oxford/Arabesque. http://dx.doi.org/10.2139/ssrn.2508281

Colbert, B. A., \& Kurucz, E. C. (2007). Three conceptions of triple bottom line business sustainability and the role for HRM. Human Resource Planning, 30(1), 21-29.

Collins, C., Steg, L., \& Koning, M. (2007). Customers' values, beliefs on sustainable corporate performance, and buying behavior. Psychology and Marketing, 24(6), 555-577. http://dx.doi.org/10.1002/mar.20173

Connelly, B. L., Ketchen, D. J., \& Slater, S. F. (2011). Toward a "theoretical toolbox" for sustainability research in marketing. Journal of the Academy of Marketing Science, 39, 86-100. http://dx.doi.org/10.1007/s11747-010-0199-0

Coombs, W. T., \& Holladay, S. J. (2015). CSR's increasing importance to corporations and corporate communication. In A. Adi, G. Grigore, \& D. Crowther (Eds.), Corporate Social Responsibility in the Digital Age, Developments in Corporate Governance and Responsibility (vol. 7, pp. 130-142). http://dx.doi.org/10.1108/S2043-052320150000007009

Core, J. E., Guay, W. R., \& Rusticus, T. O. (2006). Does weak governance cause weak stock returns? An examination of firm operating performance and investors' expectations. Journal of Finance, 61(2), 655-687. http://dx.doi.org/10.1111/j.1540-6261.2006.00851.x

Cornell, B., \& A. Shapiro. (1987). Corporate stakeholders and corporate finance. Financial Management, 5-14. http://dx.doi.org/10.2307/3665543

Corporate Watch Report. (2006). What's wrong with corporate social responsibility. Corporate Watch. Retrieved from http://www.corporatewatch.org/sites/default/files/CSRreport.pdf

Cremers, K. J. M., \& Ferrell, A. (2009). Thirty years of corporate governance: Firm valuation and stock returns. Yale ICF Working Paper No. 09-09. Retrieved from http://depot.som.yale.edu/icf/papers/fileuploads/2485/original/09-09.pdf

Cyert, R. M., \& March, J. G. (1963). A behavioral theory of the firm. Englewood Cliffs, NJ: Prentice Hall.

Daly, H. (1990). Toward some operational principles of sustainable development. Ecological Economics, 2, 1-6. http://dx.doi.org/10.1016/0921-8009(90)90010-R

Delmas, M., \& Montiel, I. (2009). Greening the supply chain: When is customer pressure effective? Journal of Economics \& Management Strategy, 18, 171-201. http://dx.doi.org/10.1111/j.1530-9134.2009.00211.x

Dhiman, S. (2008). Product, people, and planet: The triple bottom line sustainability imperative. Journal of Global Business Issues, 2(2), 51-57.

Di Meglio, F. (2012). Going green: MBA sustainability programs. Businessweek.

Ditlev-Simonsen, C. D., \& Midttun, A. (2011). What motivates managers to pursue corporate responsibility? A survey among key stakeholders. Corporate Social Responsibility and Environmental Management, 18(1), 25-38. http://dx.doi.org/10.1002/csr.237

Dixon, S. E. A., \& Clifford, A. (2007). Ecopreneurship-A new approach to managing the triple bottom line. Journal of Organizational Change Management, 20(3), 326-345. http://dx.doi.org/10.1108/09534810710740164

Doh, J. P., \& Guay, T. R. (2006). Corporate social responsibility, public policy, and NGO activism in Europe and the United States: An institutional-stakeholder perspective. Journal of Management Studies, 43, 47-73. 
http://dx.doi.org/10.1111/j.1467-6486.2006.00582.x

Donaldson, L., \& Preston, L. E. (1995). The stakeholder theory of the corporation: Concepts, evidence, and implications. Academy of Management Review, 20, 65-91.

Dunphy, D. C., Griffiths, A., \& Benn, S. (2007). Organizational change for corporate sustainability: A guide for leaders and change agents of the future. New York: Rutledge.

Doppelt, B. (2008). The power of sustainable thinking. London: Earthscan.

Dyllick, T., \& Hockerts, K. (2002). Beyond the business case for corporate sustainability. Business Strategy and the Environment, 11, 130-141. http://dx.doi.org/10.1002/bse.323

Eccles, R. G., Perkins, K. M., \& Serafeim, G. (2012). How to become a sustainable company. MIT Sloan Management Review, 53(4), 43-50.

Eco-Cycle. (2011). Recycling and environmental facts. Retrieved from http://ecocycle.org/ecofacts

El Ghoul, S., Guedhami, O., Kwok, C. C. Y., \& Mishra, D. R. (2011). Does corporate social responsibility affect the cost of capital? Journal of Banking and Finance, 35, 2388-2406. http://dx.doi.org/10.1016/j.jbankfin.2011.02.007

Elkington, J. (1994). Towards the sustainable corporation: Win-win-win business strategies for sustainable development. California Management Review, 36(2), 90-100. http://dx.doi.org/10.2307/41165746

Environmental Issues. (2012). Facts for kids about environmental issues. Retrieved from $\mathrm{http}: / / \mathrm{www}$.listofenvironmentalissues.com/environmental-issues-facts-for-kids/

Epstein, M. (2008). Making sustainability work: Best practices in managing and measuring corporate social, environmental and economic impacts. Sheffield, UK: Greenleaf Publishing.

Esquer-Peralta, J., Velazquez, L., \& Munguia, N. (2008). Perceptions of core elements for sustainability

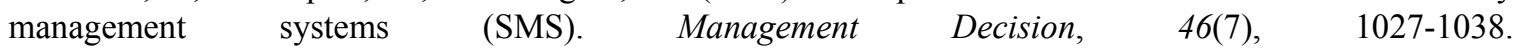
http://dx.doi.org/10.1108/00251740810890195

Etzion, D. (2007). Research on organizations and the natural environment, 1992-present: A review. Journal of Management, 33, 637-644. http://dx.doi.org/10.1177/0149206307302553

Faupel, C., \& Schwach, S. (2010). Measuring corporate sustainability, maximizing shareholder value. Retrieved from

http://performance.ey.com/wp-content/uploads/2011/05/Measuring-corporate-sustainability-maximizing-sha reholder-value.pdf

Figge, F., \& Hahn, T. (2004). Sustainable value added-measuring corporate contributions to sustainability $\begin{array}{lllll}\text { beyond } & \text { eco-efficiency. } & \text { Ecological } & \text { Economics, } & \text { 48(2), }\end{array}$ http://dx.doi.org/10.1016/j.ecolecon.2003.08.005

Figge, F., Hahn, T., Schaltegger, S., \& Wagner, J. (2002). The sustainability balanced scorecard-Linking sustainability management to business strategy. Business Strategy, and the Environment, 11, 269-284. http://dx.doi.org/10.1002/bse.339

Freeman, R. E. (1984). Strategic management: A stakeholder approach. Boston: Pitman Books.

Fukuyama, F. (1999). Social capital and civil society. Institute of Public Policy, George Mason University. Delivered at the IMF Conference on Second Generation Reforms.

Ghosh, J. (2008). We need a paradigm shift. International Development Economics Associates. Retrieved from http://www.networkideas.org/news/oct2008/news27_Shift.htm

Giroud, X., \& Mueller, H. M. (2011). Corporate governance, product market competition, and equity prices. Journal of Finance, 66(2), 563-600. http://dx.doi.org/10.1111/j.1540-6261.2010.01642.x

Godfrey, P. C., Merrill, C. B., \& Hansen, J. M. (2009). The relationship between corporate social responsibility and shareholder value: An empirical test of the risks management hypothesis. Strategic Management Journal, 30, 425-445. http://dx.doi.org/10.1002/smj.750

Goel, P. (2010). Triple bottom line reporting: An analytical approach for corporate sustainability. Journal of Finance, Accounting, and Management, 1(1), 27-42.

Goss, A., \& Roberts, G. S. (2011). The Impact of Corporate Social Responsibility on the Cost of Bank Loans. Journal of Banking and Finance, 35, 1794-1810. http://dx.doi.org/10.1016/j.jbankfin.2010.12.002 
Graham, R., \& Bertels, S. (2008). Achieving sustainable value: Sustainability portfolio assessment. Greener Management International, 54, 57-67.

Gregory, A., \& Whittaker, J. (2013). Exploring the valuation of corporate social responsibility-A comparison of research methods. Journal of Business Ethics, 116(1), 1-20. http://dx.doi.org/10.1007/s10551-012-1465-5

Gupta, N. J., \& Benson, C. C. (2011). Sustainability and competitive advantage: An empirical study of value creation. Competition Forum, 9(1), 121-136.

Hahn, R. (2011). Integrating corporate responsibility and sustainable development: A normative-conceptual approach to holistic management thinking. Journal of Global Responsibility, 2(1), 8-22. http://dx.doi.org/10.1108/20412561111128492

Hahn, T., Figge, F., \& Barkemeyer, R. (2007). Sustainable value creation among companies in the manufacturing sector. International Journal of Environmental Technology and Management, 7(5/6), 496-512. http://dx.doi.org/10.1504/ijetm.2007.015627

Hakensen, D. (2010). Sustainability, defined? Minnesota Business Magazine. Retrieved from $\mathrm{http} / / /$ minnesotabusiness.com/sustainability-defined

Harrison, J. S., \& Freeman, R. E. (1999). Stakeholders, social responsibility, and performance: Empirical evidence and theoretical perspectives. Academy of Management Journal, 42(5), 479-485. http://dx.doi.org/10.2307/256971

Hart, S. L., \& Milstein, M. B. (2003). Creating sustainable value. Academy of Management Executive, 17(2), 56-69. http://dx.doi.org/10.5465/AME.2003.10025194

Haugh H. M., \& Talwar, A. (2010). How do corporations embed sustainability across the organization? Academy of Management Learning \& Education, 9, 384-396. http://dx.doi.org/10.5465/AMLE.2010.53791822

Hawken, P., Lovins, A., \& Lovins, H. (1999). Natural capitalism: creating the next industrial revolution. London: Earthscan.

Hespenheide, E., \& Koehler, D. A. (2012). Disclosure of long-term business value. What matters? Deloitte Research. Retrieved from http://dupress.com/articles/disclosure-of-long-term-business-value/

Hiller, J. S. (2013). The benefit corporation and corporate social responsibility. Journal of Business Ethics, 118(2), 287-301. http://dx.doi.org/10.1007/s10551-012-1580-3

Hillman, J. A., \& Keim, D. G. (2001). Shareholder value, stakeholder management, and social issues: What's the $\begin{array}{lllll}\text { bottom line? Strategic } & \text { Management } & \text { Journal, }\end{array}$ $\mathrm{http}: / / \mathrm{dx}$. doi.org/10.1002/1097-0266(200101)22:2\%3C125::AID-SMJ150\%3E3.0.CO;2-H

Ho, L., \& Taylor, M. (2007). An empirical analysis of triple bottom-line reporting and its determinants: Evidence from the United States and Japan. Journal of International Financial Management and Accounting, 18(2), 123-150. http://dx.doi.org/10.1111/j.1467-646X.2007.01010.x

Hoffman, A., Badiane, K., \& Haigh, N. (2012). Hybrid Organizations as agents of positive social change: Bridging the for-profit and non-profit divide. In K. Golden-Briddle \& J. E. Dutton (Eds.), Using a Positive Lens to Explore Social Change and Organizations (pp. 131-153). Hoboken: Taylor and Francis.

Høivik, H. W., \& Shankar, D. (2011). How can SMEs in a cluster respond to global demands for corporate responsibility? Journal of Business Ethics, 101(2), 175-195. http://dx.doi.org/10.1007/s10551-010-0708-6

Husted, B., \& Allen, D. (2006). Corporate social responsibility in the multinational enterprise: Strategic and institutional approaches. Journal of International Business Studies, 37, 838-849.

Husted, B. W., \& Salazar, J. D. J. (2006). Taking Friedman seriously: Maximizing profits and social performance. Journal of Management Studies, 43(1), 75-91. http://dx.doi.org/10.1111/j.1467-6486.2006.00583.x

Jackson, A., Boswell, K., \& Davis, D. (2011). Sustainability and triple bottom line reporting-what is all about? International Journal of Business, Humanities and Technology, 1(3), 55-59.

Jensen, M. C. (2001). Value maximization, stakeholder theory, and the corporate objective function. Journal of Applied Corporate Finance, 14(3), 8-21. http://dx.doi.org/10.1111/j.1745-6622.2001.tb00434.x

Jensen, J. C., \& Berg, N. (2012). Determinants of traditional sustainability reporting versus integrated reporting. An institutionalist approach. Business Strategy and the Environment, 21, 299-316. http://dx.doi.org/10.1002/bse.740 
Jeucken, M. (2005). Sustainability in finance — banking on the planet. University of Chicago Press.

Johnson, Marilyn. (2014). Corporate sustainability: The ever evolving business imperative. Environmental Leader. http://www.environmentalleader.com/2014/10/21/corporate-sustainability-the-ever-evolving-business-imper ative/

Jones, P., Clarke-Hill, C., Comfort, D., \& Hillier, D. (2007). Marketing and sustainability. Marketing Intelligence and Planning, 26(2), 123-130. http://dx.doi.org/10.1108/02634500810860584

Jones, T. M. (1995). Instrumental stakeholder theory: A synthesis of ethics and economics. Academy of Management Review, 20, 404-437.

Kacperczyk, A. (2009). With greater power comes greater responsibility? Takeover protection and corporate attention to stakeholders. Strategic Management Journal, 30, 261-281. http://dx.doi.org/10.1002/smj.733

Kaplan, R. S., \& Norton, D. P. (1992). The balanced scorecard-Measures that drive performance. Harvard Business Review, 71-79.

Kaptein, M., \& Wempe, J. (2001). Sustainability management—balancing conflicting economic, environmental, and social corporate responsibilities. Journal of Corporate Citizenship, 1(2), 91-106. http://dx.doi.org/10.9774/GLEAF.4700.2001.su.00011

Kassinis, G., \& Vafeas, N. (2006). Stakeholder pressures and environmental performance. Academy of Management Journal, 49(1), 145-159. http://dx.doi.org/10.5465/AMJ.2006.20785799

Kelly, M., \& White, A. L. (2009). From corporate responsibility to corporate design: Rethinking the purpose of the corporation. Journal of Corporate Citizenship, 33, 23-27. http://dx.doi.org/10.9774/GLEAF.4700.2009.sp.00005

Key, S. (1999). Toward a new theory of the firm: a critique of stakeholder "theory". Management Decision, 37(4), 317-328. http://dx.doi.org/10.1108/00251749910269366

Kock, C. J., Santaló, J., \& Diestre, L. (2012). Corporate governance and the environment: What type of governance creates greener companies? Journal of Management Studies, 49, 492-514. http://dx.doi.org/10.1111/j.1467-6486.2010.00993.x

Kuosmanen, T., \& Kuosmanen, N. (2009). How not to measure sustainable value (and how one might). Ecological Economics, 69(2), 235-243. http://dx.doi.org/10.1016/j.ecolecon.2009.08.008

Lamberton, G. (2005). Sustainability accounting-a brief history and conceptual framework. Accounting Forum, 29(1), 7-26. http://dx.doi.org/10.1016/j.accfor.2004.11.001

Laszlo, K. C. (2001, July). The evolution of business: Learning, innovation and sustainability in the 21 st century. International Society for the Systems Sciences (ISSS), Asilomar, California. Retrieved from https://www.oasis-open.org/committees/download.php/\%2020459/06-09-00014.000.pdf

Lima, B. F., \& Sanvicente, A. Z. (2013). Quality of corporate governance and cost of equity in Brazil. Journal of Applied Corporate Finance, 25(1), 72-80. http://dx.doi.org/10.1111/j.1745-6622.2013.12008.x

Linnenluecke, M. K., \& Griffiths, A. (2010). Corporate sustainability and organizational culture. Journal of World Business, 45(4), 357-366. http://dx.doi.org/10.1016/j.jwb.2009.08.006

Lülfs, R., \& Hahn, R. (2014). Sustainable behavior in the business sphere: A comprehensive overview of the explanatory power of psychological models. Organization \& Environment, 27(1), 43-64. http://dx.doi.org/10.1177/1086026614522631

Maas, K., \& Liket, K. (2011). Talk the walk: Measuring the impact of strategic philanthropy. Journal of Business Ethics, 100, 445-464. http://dx.doi.org/10.1007/s10551-010-0690-z

Magee, D. (2009). Jeff Immelt and the new GE way: Innovation, transformation and winning in the 21st century. New York: McGraw-Hill.

Manzini, E. (2002). Context-based wellbeing and the concept of regenerative solution: A conceptual framework for scenario building and sustainable solutions development. Journal of Sustainable Product Design, 2, 141-148. http://dx.doi.org/10.1023/B:JSPD.0000031026.11908.1d

Maon, F., Lindgreen, A., \& Swaen, V. (2009). Designing and implementing corporate social responsibility: An integrative framework grounded in theory and practice. Journal of Business Ethics, 87(S1), 71-89. http://dx.doi.org/10.1007/s10551-008-9804-2 
Margolis, J., \& Walsh, J. (2003). Misery loves companies: Rethinking social initiatives in business. Administrative Science Quarterly, 48, 403-441. http://dx.doi.org/10.2307/3556659

Markevich, A. (2009). The evolution of sustainability. MIT Sloan Management Review, 51(1), 13-14.

Marshall, R. S., \& Brown, D. (2003). The strategy of sustainability: A systems perspective on norm thompson outfitters' environmental stewardship initiatives. California Management Review, 46, 101-126. http://dx.doi.org/10.2307/41166234

Martin, G. (2013). Evolution of sustainability: How going green is becoming an essential business practice. Smart Business Network. Retrieved from http://www.mossadams.com/mossadams/media/Documents/Publications/Real\%20Estate/Nca_MossAdams_ 0213.pdf

Mattingly, J. E. (2015). Corporate social performance: A review of empirical research examining the corporation-society relationship using Kinder, Lydenberg, Domini social rating data. Business \& Society, 54, Abstract. http://dx.doi.org/10.1177/0007650315585761

Maxfield, S. (2008). Reconciling corporate citizenship and competitive strategy: Insights from economic theory. Journal of Business Ethics, 80(2), 367-377. http://dx.doi.org/10.1007/s10551-007-9425-1

McDonald, S., \& Oates, C. J. (2006). Sustainability: Consumer perceptions and marketing strategies. Business Strategy and the Environment, 15(3), 157-170. http://dx.doi.org/10.1002/bse.524

McIntosh, M., Leipziger, D., Jones, K., \& Coleman, Gill. (1998). Corporate citizenship: Successful strategies for responsible companies. London: Financial Times Pitman Publishing.

McKinsey \& Company. (2011). The business of sustainability: McKinsey Global Survey Results. Retrieved from http://www.mckinsey.com/insights/energy_resources_materials/the_business_of_sustainability_mckinsey_g lobal_survey_results

McLamb, E. (2009). Sustainable evolution of the economy, business and industry. Ecology Communications Group-Business \& Economy. Retrieved from http://www.ecology.com/2009/01/27/sustainable-evolution-of-the-economy-business-and-industry/

McWilliams, A., \& Siegel, D. (2011). Creating and capturing value: Corporate social responsibility, resourcebased theory, and sustainable competitive advantage. Journal of Management, 37, 1480-1495. http://dx.doi.org/10.1177/0149206310385696

Metcalf, L., \& Benn, S. (2013). Leadership for sustainability. An evolution of leadership ability. Journal of Business Ethics, 112(3), 369-384.

Montiel, I. (2008). Corporate social responsibility and corporate sustainability: Separate pasts, common futures. Organization \& Environment, 21, 245-269. http://dx.doi.org/10.1177/1086026608321329

Montiel, I., \& Delgado-Ceballos, J. (2014). Defining and measuring corporate sustainability: Are we there yet? Organization \& Environment, 27, 113-139. http://dx.doi.org/10.1177/1086026614526413

Moon, J., \& Orlitzky, M. (2011). CSR and sustainability education: A trans-Atlantic comparison. Journal of Management and Organization, 17(5), 583-603. http://dx.doi.org/10.5172/jmo.2011.17.5.583

Morhardt J. E. (2009). Corporate social responsibility and sustainability reporting on the Internet. Business Strategy and the Environment, 9, 436-452. http://dx.doi.org/10.1002/bse.657

Moura-Leite, R. C., Padgett, R. C., \& Galan, J. I. (2014). Stakeholder management and nonparticipation in controversial business. Business \& Society, 53(1), 45-70. http://dx.doi.org/10.1177/0007650310395547

Muthuri, J. N., Matten, D., \& Moon, J. (2009). Employee volunteering and social capital: Contributions to corporate social responsibility. British Journal of Management, 20, 75-89.

Nadkarni, A. G., \& Branzei, O. (2008). The Tata way: Evolving and executing sustainable business strategies. Ivey Business Journal. Retrieved from http://iveybusinessjournal.com/publication/the-tata-way-evolving-and-executing-sustainable-business-strate gies/

Nadeem, M. (2013). Emerging markets: Corporate sustainability or maximize stakeholder value? International Journal of Humanities and Social Science, 3(5), 91-107.

Neubaum, D. O., \& Zahra, S. A. (2006). Institutional ownership and corporate social performance: The moderating effects of investment horizon, activism, and coordination. Journal of Management, 32(1), 
108-131. http://dx.doi.org/10.1177/0149206305277797

Neumayer, E. (1999). Weak versus strong sustainability: Exploring the limits of two opposing paradigms. Cheltenham: Elgar.

Nidumolu, R., Prahalad, C. K., \& Rangaswami, M. R. (2009, September). Why sustainability is now the key driver of innovation. Harvard Business Review. Retrieved from https://hbr.org/2009/09/why-sustainability-is-now-the-key-driver-of-innovation

Nordheim, E., \& Barrasso, G. (2007). Sustainable development indicators of the European aluminum industry. Journal of Cleaner Production, 15(3), 275-279. http://dx.doi.org/10.1016/j.jclepro.2006.02.004

Norman, W., \& MacDonald, C. (2004). Getting to the bottom of the triple bottom line. Business Ethics Quarterly, 2(14), 243-262. http://dx.doi.org/10.5840/beq200414211

Orlitzky, M., Schmidt, F., \& Rynes, S. (2003). Corporate social and financial performance: A meta-analysis. Organization Studies, 24, 403-441. http://dx.doi.org/10.1177/0170840603024003910

Orlitzky, M., Siegel, D. S., \& Waldman, D. A. (2011). Strategic corporate social responsibility and environmental sustainability. Business \& Society, 50(1). 6-27. http://dx.doi.org/10.1177/0007650310394323

Pache, A.-C., \& Santos, F. (2013). Inside the hybrid organization: selective coupling as a response to competing institutional logics. Academy of Management Journal, 56(4), 972-1001. http://dx.doi.org/10.5465/amj.2011.0405

Pearce, D., Markandya, A., \& Barbier, E. B. (1989). Blueprint for a green economy. London: Earthscan.

Peattie, K. (2001). Towards sustainability: The third age of green marketing. Marketing Review, 2(2), 129-146. http://dx.doi.org/10.1362/1469347012569869

Peloza, J., Loock, M., Cerruti, J., \& Muyot, M. (2012). Sustainability: How stakeholder perceptions differ from corporate reality. California Management Review, 55(1), 74-95. http://dx.doi.org/10.1525/cmr.2012.55.1.74

Peters, R., \& Caro, C. A. (2014). Corporate social responsibility and sustainability responsiveness in business schools: A classification scheme. Journal of Sustainability Management, 2(1), 1-8.

Pfeffer, J. (2010). Building sustainable organizations: The human factor. Academy of Management Perspectives, 24(1), 34-45. http://dx.doi.org/10.5465/AMP.2010.50304415

Polman, P. (2014). Business, society, and the future of capitalism. Commentary McKinsey Quarterly. Retrieved from http://www.mckinsey.com/insights/sustainability/business_society_and_the_future_of_capitalism

Porter, M. E., \& Kramer, M. R. (2006). Strategy and society: The link between competitive advantage and corporate social responsibility. Harvard Business Review, 84(12), 78-92.

Porter, M. E., \& Kramer, M. R. (2011). Creating shared value: How to reinvent capitalism and unleash a way of innovation and growth. Harvard Business Review, 62-77.

Porter, M. E., Hills, G., Pfitzer, M., Patscheke, S., \& Hawkins, E. (2012). Measuring shared Value: How to unlock value by linking business and social results. FSG Report. Retrieved from https://sharedvalue.org/sites/default/files/resource-files/Measuring_Shared_Value.pdf

Prahalad, C. K. (1994). Corporate governance or corporate value added?: Rethinking the primacy of shareholder value. Journal of Applied Corporate Finance, 6(4), 40-50. http://dx.doi.org/10.1111/j.1745-6622.1994.tb00247.x

Raatzsch, R. (2012). On the notion of sustainability. Inquiry, 55(4), 361-385. http://dx.doi.org/10.1080/0020174X.2012.696349

Reid, E. M., \& Toffel, M. W. (2009). Responding to public and private politics: Corporate disclosure of climate change strategies. Strategic Management Journal, 30, 1157-1178. http://dx.doi.org/10.1002/smj.796

Reinecke, J., Manning, S., \& von Hagen, O. (2012). The emergence of a standards market: Multiplicity of sustainability standards in the global coffee industry. Organization Studies, 33, 791-814. http://dx.doi.org/10.1177/0170840612443629

Ricart, J. E., Rodriguez, M. A., \& Sanchez, P. (2006). Sustainability in the boardroom. Corporate Governance, $5(3), 24-41$.

Roome, N. (2005). Stakeholder power and organizational learning in corporate environmental management. Organization Studies, 27(2), 235-263. http://dx.doi.org/10.1177/0170840605057669 
Rueda-Manzanares, A., Aragón-Correa, J. A., \& Sharma, S. (2008). The influence of stakeholders on the environmental strategy of service firms: The moderating effects of complexity, uncertainty and munificence. British Journal of Management, 19, 185-203. http://dx.doi.org/10.1111/j.1467-8551.2007.00538.x

Russo, M., \& Fouts, P. (1997). A resource-based perspective on corporate environmental performance and profitability. Academy of Management Journal, 40, 534-559. http://dx.doi.org/10.2307/257052

Salzmann, O., Ionescu-Somers, A., \& Steger, U. (2005). The business case for corporate sustainability: Literature review and research options. European Management Journal, 23(1), 27-36. http://dx.doi.org/10.1016/j.emj.2004.12.007

Savitz, A. W. (2013). The triple bottom line. How today's best-run companies are achieving economic, social and environmental success-and how you can too. New York: Jossey-Bass.

Schaltegger, S., Lüdeke-Freund, F., \& Hansen, E. (2012). Business cases for sustainability: The role of business model innovation for corporate sustainability, International Journal of Innovation and Sustainable Development, 6(2), 95-119. http://dx.doi.org/10.1504/IJISD.2012.046944

Searcy, C. (2009). The role of sustainable development indicators in corporate decision-making. International Institute for Sustainable Development (IISD). $\quad$ Retrieved from http://www.iisd.org/pdf/2009/role_of_sustainability_indicators.pdf

Sen, S., Bhattacharya, C. B., \& Korschun, D. (2006). The role of corporate social responsibility in strengthening multiple stakeholder relationships: A field experiment. Journal of the Academy of Marketing Science, 34(2), 158-166. http://dx.doi.org/10.1177/0092070305284978

Servaes, H., \& Tamayo, A. (2013). The impact of corporate social responsibility on firm value: The role of customer awareness. Management Science, 59(5), 1045-1061. http://dx.doi.org/10.1287/mnsc.1120.1630

Sharma, A. (2013a). The sustainable value of "Brand Disney": Strategic implications of its withdrawal from Bangladesh. Sustainable Brands. Retrieved from http://www.sustainablebrands.com/news_and_views/social_enterprise/sustainable-value-brand-disney-strate gic-implications-its-withdrawa

Sharma, A. (2013b). Oil, money and global warming: How Shell is tackling the challenges of energy, economy and climate change. Sustainable Brands. Retrieved from http://www.sustainablebrands.com/news_and_views/articles/oil-money-and-global-warming-how-shell-tack ling-challenges-energy-economy-an

Shrivastava, P. (1995). The role of corporations in achieving ecological sustainability. Academy of Management Review, 20, 936-960.

Shrivastava, P., \& Kennelly, J. J. (2013). Sustainability and place-based enterprise. Organization \& Environment, 26, 83-101. http://dx.doi.org/10.1177/1086026612475068

Siebenhüner, B., \& Arnold, M. (2007). Organizational learning to manage sustainable development. Business Strategy \& the Environment, 16(5), 339-353. http://dx.doi.org/10.1002/bse.579

Smithley-Fulmer, I., Gerhart, B., \& Scott, K. S. (2003). Are the 100 best better? An empirical investigation of the relationship between being a "Great Place to Work" and firm performance. Personnel Psychology, 56, 965-993. http://dx.doi.org/10.1111/j.1744-6570.2003.tb00246.x

Solomon, R. C., \& Hanson, K. R. (1983). Above the bottom line: An introduction to business ethics. New York: Harcourt Brace Jovanovich.

Sontag-Padilla, L. M., Staplefoote, L., \& Morganti, K. G. (2012). Financial sustainability for nonprofit organizations: A review of the literature. The RAND Corporation Research Report. Retrieved from http://www.rand.org/content/dam/rand/pubs/research_reports/RR100/RR121/RAND_RR121.pdf

Soppe, A. (2009). Sustainable finance as a connection between corporate social responsibility and social responsible investing. Indian Management Research Journal, 1(3), 13-23.

Sotorrio, L. L., \& Sanchez, J. L. F. (2008). Corporate social responsibility of the most highly reputed European and North American firms. Journal of Business Ethics, 82, 379-390. http://dx.doi.org/10.1007/s10551-008-9901-2

Starik, M. (2013). Organization \& Environment: Present, past and future. Organization \& Environment, 26 , 239-240. http://dx.doi.org/10.1177/1086026613499233 
Starik, M., \& Kanashiro, P. (2013). Toward a theory of sustainability management: Uncovering and integrating the nearly obvious. Organization \& Environment, 26, 7-30. http://dx.doi.org/10.1177/1086026612474958

Statman, M., \& Glushkov, D. (2009). The wages of social responsibility. Financial Analysts Journal, 65(4), 33-46. http://dx.doi.org/10.2469/faj.v65.n4.5

Stead, J. G., \& Stead, W. E. (2008). Sustainable strategic management: an evolutionary perspective. International Journal of Sustainable Strategic Management, 1(1), 62-81. http://dx.doi.org/10.1504/IJSSM.2008.018127

Stern, D. (1997). The capital theory approach to sustainability: A critical appraisal. Journal of Economic Issues, 31, 145-173. http://dx.doi.org/10.1080/00213624.1997.11505895

Stern, P. C., Dietz, T., Abel, T., Guagnano, G. A., \& Kalof, L. (1999). A value-belief-norm theory of support for social movements: The case of environmental concern. Human Ecology Review, 6, 81-97.

Stormer, F. (2003). Making the Shift: Moving from "Ethics Pays" to an Inter-Systems Model of Business. Journal of Business Ethics, 44(4), 279-289. http://dx.doi.org/10.1023/A:1023600820194

Straková, J. (2012). Are manufacturing companies improving their sustainable value added? Ekonomiká Revue, 15, 225-236. http://dx.doi.org/10.7327/cerei.2012.12.03

Strandberg, C. (2009). The role of human resource management in corporate social responsibility: Issue brief and roadmap. Strandberg http://www.al-qadeem.com/images/white-papers/CSR_and_HR_Management1.pdf

Consulting.

Strike, V. M., Gao, J., \& Bansal, P. (2006). Being good while being bad: Social responsibility and the international diversification of US firms. Journal of International Business Studies, 37, 850-862. http://dx.doi.org/10.1057/palgrave.jibs.8400226

Stubbs, W., \& Cocklin, C. (2008). Conceptualizing a sustainability business model. Organization \& Environment, 21(2), 103-127. http://dx.doi.org/10.1177/1086026608318042

Surroca, J., Tribó, J. A., \& Zahra, S. (2013). Stakeholder pressure on MNEs and the transfer of socially irresponsible practices to subsidiaries. Academy of Management Journal, 56, 549-572. http://dx.doi.org/10.5465/amj.2010.0962

Swenson, R. B. (1996). Nurture capital—A new paradigm for business. Ecotopia Manuscripts. Retrieved from http://www.ecotopia.com/webpress/nurcap/index.html

Szekely, F., \& Knirsch, M. (2005). Responsible leadership and corporate social responsibility: Metrics for sustainable performance. European Management Journal, 23, 628-647. http://dx.doi.org/10.1016/j.emj.2005.10.009

The World Commission on Environment and Development. (1987). Our common future. The Brundtland Report. Oxford: Oxford University Press.

Van der Byl, C. A., \& Slawinski, N. (2015). Embracing tensions in corporate sustainability: A review of research from win-wins and trade-offs to paradoxes and beyond. Organization \& Environment, 28(1), 54-79. http://dx.doi.org/10.1177/1086026615575047

Valente, M. (2012). Theorizing firm adoption of sustaincentrism. Organization Studies, 33, 563-591. http://dx.doi.org/10.1177/0170840612443455

Vallester, C., Lindgren, A., \& Moan, F., (2012). Strategically leveraging CSR: A corporate branding perspective. California Management Review, 54(3), 34-60. http://dx.doi.org/10.1525/cmr.2012.54.3.34

Van Marrewijk, M. (2003). Concepts and definitions of CSR and corporate sustainability: Between agency and communion. Journal of Business Ethics, 44(2/3), 895-105.

Van Passel, S., Van Huylenbroeck, G., Lauwers, L., \& Mathius, E. (2009). Sustainable value assessment of farms using frontier efficiency benchmark. Journal of Environmental Management, 90(10), 3057-3069. http://dx.doi.org/10.1016/j.jenvman.2009.04.009

Verwijmeren, P., \& Derwall, J. (2010). Employee well-being, firm leverage, and bankruptcy risk. Journal of Banking and Finance, 34, 956-964. http://dx.doi.org/10.1016/j.jbankfin.2009.10.006

Visser, W. (2010). The age of responsibility: CSR 2.0 and the new DNA of business. Journal of Business Systems, Governance and Ethics, 5(3), 7-22.

Visser, W., \& Crane, A. (2010) Corporate sustainability and the individual: Understanding what drives 
sustainability professionals as change agents. SSRN eLibrary. http://dx.doi.org/10.2139/ssrn.1559087

Vogel, D. (2005). The market for virtue: The potential and limits of corporate social responsibility. Washington, DC: Brookings Institution Press.

Vorhies, D. W., \& Morgan, N. A. (2005). Benchmarking marketing capabilities for sustainable competitive advantage. Journal of Marketing, 69(1), 80-94. http://dx.doi.org/10.1509/jmkg.69.1.80.55505

Walls, J., Berrone, P., \& Phan, P. (2012). Corporate governance and environmental performance: Is there really a link? Strategic Management Journal, 33, 885-913. http://dx.doi.org/10.1002/smj.1952

Wei-Skillern, J. (2004). The evolution of Shell's stakeholder approach: A case study. Business Ethics Quarterly, 14(4), 713-728. http://dx.doi.org/10.5840/beq200414443

Werther, W. B., Jr., \& Chandler, D. (2011). Strategic corporate social responsibility: Stakeholders in a global environment (2nd ed.). Los Angeles: Sage.

Wheeler, D., \& Sillanpaa, M. (1997). The stakeholder corporation. London: Pitman Publishing.

Willard, B. (2009). The sustainability champion's guidebook. Gabriola Island, British Columbia: New Society Publishers.

Wilson, M. (2003). Corporate sustainability: What is it and where does it come from? Ivey Business Journal. Retrieved from http://iveybusinessjournal.com/publication/corporate-sustainability-what-is-it-and-where-does-it-come-from

Wirtenberg, J., Russell, W. G., \& Lipsky, D. (2008). The sustainable enterprise fieldbook: When it all comes together. New York: AMACOM.

Wycherley, I. (1999). Greening supply chains: The case of the Body Shop International. Business Strategy and the Environment, $\quad 8(2), \quad 120-127$. http://dx.doi.org/10.1002/(SICI)1099-0836(199903/04)8:2\%3C120::AID-BSE188\%3E3.0.CO;2-X

Zollo M., Cennamo C., \& Neumann K. (2013). Beyond what and why: Understanding organizational evolution towards sustainable enterprise models. Organization \& Environment, 26, 241-259. http://dx.doi.org/10.1177/1086026613496433

\section{Copyrights}

Copyright for this article is retained by the author(s), with first publication rights granted to the journal.

This is an open-access article distributed under the terms and conditions of the Creative Commons Attribution license (http://creativecommons.org/licenses/by/3.0/). 